\title{
Building condition assessment: adjustments of the Building Performance Indicator (BPI) for university buildings in Brazil
}

\author{
Avaliação da condição do edifício: ajustes do Building \\ Performance Indicator (BPI) para edificações \\ universitárias brasileiras
}

\begin{abstract}
Francisco Morato Leite
Renan Alves Volse

Humberto Ramos Roman

Fernanda Aranha Saffaro

Abstract

he Building Performance Indicator (BPI), not fully applied in Brazil, expresses objectively the overall condition of a building based on the performance assessment of the building systems that comprise it. Although BPI was originally developed for hospital facilities, it can be used in different types of buildings since its methodology is generic. The objective of the study is to adjust the BPI to allow its application in the maintenance management of Brazilian university buildings. The stages of the research consist of (1) adjusting the factors and criteria that comprise the BPI; (2) implementing the adapted BPI; and (3) verifying its utility and ease of use. The adjustment and implementation included a building for classrooms and another that houses a teaching and research laboratory, both located at University $\mathrm{X}$. The results obtained allowed the comparison of the overall condition between the inspected buildings, which establishes the intervention priority helping to adopt the most adequate maintenance strategy.
\end{abstract}

${ }^{1}$ Francisco Morato Leite Universidade Estadual de Londrina Londrina - PR - Brasil

${ }^{2}$ Renan Alves Volse Londrina - PR - Brasil

${ }^{3}$ Humberto Ramos Roman Universidade Federal de Santa Catarina Florianópolis - SC - Brasil

${ }^{4}$ Fernanda Aranha Saffaro Universidade Estadual de Londrina E-mail: saffaro@uel.br

Recebido em 21/03/19 Aceito em 14/07/19
Keywords: Building maintenance management. Building condition assessment. Building performance indicator.

\section{Resumo}

O indicador BPI (Building Performance Indicator), ainda pouco aplicado no Brasil, expressa de maneira objetiva a condição global da edificação a partir da avaliação do desempenho dos seus sistemas construtivos. Embora o BPI tenha sido desenvolvido, inicialmente, para as instalações hospitalares, observa-se a possibilidade de aplicação em diferentes tipos de edificações uma vez que seu procedimento de obtenção é genérico. O objetivo da pesquisa é ajustar o BPI para permitir a sua aplicação na gestão da manutenção de edificações universitárias no Brasil. As etapas da pesquisa consistiram em: ajuste dos fatores e critérios que compõem o BPI; implementação do BPI ajustado; e verificação da utilidade e facilidade de uso. $O$ ajuste e implementação abrangeram um edifício destinado a salas de aulas e outro que abriga um laboratório de ensino e pesquisa, ambos localizados na Universidade $X$. Os resultados obtidos propiciaram a comparação da condição global entre as edificações, o que permite estabelecer a prioridade de intervenção e auxiliar na adoção da estratégia de manutenção mais adequada.

Palavras-chave: Gestão da manutenção predial. Avaliação da condição da edificação. Indicador de desempenho da edificação.

LEITE, F. M.; VOLSE, R. A.; ROMAN, H. R.; SAFFARO, F. A. Building condition assessment: adjustments of the Building Performance Indicator (BPI) for university buildings in Brazil. Ambiente Construído, Porto Alegre, v. 20, n. 1, p. 215230, jan./mar. 2020.

ISSN 1678-8621 Associação Nacional de Tecnologia do Ambiente Construído. http:// dx. doi. org/ 10.1590/ s1678-86212020000100370 


\section{Introduction}

Universities are generally supported by an extensive portfolio consisting of different types of construction, dimensions, construction ages, forms of use and occupancy rates.

Inevitably, buildings deteriorate over time, resulting in a reduced capacity to meet the functions for which they were designed and built. The physical condition of buildings affects the quality of the services provided. As pointed out by Lateef, Khamidi and Idrus (2011), several recent studies confirm the positive correlation between building performance and quality of education.

Building maintenance has strategic importance since universities need their spaces in proper conditions in the longest available time and with lower operational costs. These conditions support the achievement of their mission and success in the organisational goals.

Abbott et al. (2007) stated that maintenance can only be effectively managed if the demand for maintenance activities is adequately quantified. Reliable and objective knowledge of the buildings' state and the impacts on the services provided by them will enable managers to develop appropriate strategies and actions for maintenance (DEPARTMENT..., 2017). On the contrary, as Dejaco, Cecconi and Maltese (2017) have emphasised, the lack of information on the current state of buildings leads to the use of unsafe buildings, poor building performance and low-income investments.

Due to this, methods for the Building Condition Assessment (BCA) are considered primordial for building maintenance management (NATIONAL..., 2003b; ABBOTT et al., 2007; AHLUWALIA, 2008; EWEDA; ZAYED; ALKASS, 2010). The implementation of BCA makes it possible to systematise the data collected locally into information useful for decision making.

BCA can be applied to all types of buildings (ROYAL..., 2005). However, the development of BCA in Brazil is restricted to the application in the structural system in reinforced concrete of buildings or bridges. In this case, the method developed by Castro (1994) from Klein et al. (1991), with modifications from Lopes (1998), Boldo (2002) and Fonseca (2007) are highlighted.

In search of a method for BCA applicable to the complexity of the building maintenance management of university campuses in the country, the literature review pointed out the work of Shohet, Lavy-Leibovich and Bar-On (2003). The authors have developed research related to the maintenance management of public hospital facilities in Israel, proposing integrated key performance indicators (KPIs) as a basis for the strategic planning of building maintenance. Among the KPIs, Shohet (2003) described the building performance indicator (BPI) that objectively expresses, on a scale from zero to 100 , the overall state of a building by assessing the condition of each of its constructive systems. Besides considering the state of conservation of the building, BPI is based on economic aspects of maintenance. Due to its formation, BPI evaluates not only the overall state of the building, but also the systems that comprise it. In addition, it provides inter and intraorganisational benchmarking and makes it possible to decide on the most appropriate maintenance strategy.

Although BPI has been developed for the maintenance management of hospital facilities, this indicator can be used in different types of buildings since the methodology for its formulation can be generalised by adjusting the factors and criteria that comprise it.

Therefore, the main objective of the study is to adjust the BPI proposed by Shohet (2003) to the constructive characteristics of university buildings in order to use it in building maintenance management of university campuses.

The expected contribution is the availability of a useful tool for the strategic and tactical maintenance management of university buildings. In addition, the description of the procedures for adjusting BPI makes it possible to apply it in other types of buildings.

The results obtained in this study are part of broader research that aims to propose an integrated set of performance indicators for the maintenance management of university buildings.

\section{Building Condition Assessment (BCA)}

BCA is defined in different ways in the literature. BCA is a tool for strategic management to support longterm building maintenance forecasting (STRAUB, 2002). According to Uzarski and Grussing (2008), BCA consists of translating the inspection data into one or more indicators that report the building condition and allow better decision making regarding maintenance management. These definitions agree with the established practice in ASCE/SEI 30-14 technical standards (AMERICAN..., 2014) that report the BCA potential to 
identify any discrepancy between current and expected performance of a building, to plan maintenance activities, and also comply with the regulations (legislation).

Elhakeem (2005) and Ahluwalia (2008) describe the four steps that comprise BCA:

(a) the breakdown of the building into its main parts;

(b) the definition of procedures for assessment;

(c) the building inspection and data collection; and

(d) analysis of inspection data. In the literature, they are characterised by:

- the breakdown deals with the division of the building into its main parts, allowing the assessment of their condition. The breakdown occurs in a stratification, starting with clustering the parts of the building in systems (structural, facade, roof, hydro-sanitary installations, etc.). In general, the criterion for clustering is the usability and/or association of degradation mechanisms. Afterwards, the breakdown of each system can occur at hierarchically lower functional levels, elements until reaching the components of construction;

- the procedures for the condition assessment of the building's parts are generally distinguished in a survey of constructive anomalies and direct classification of the condition. Regarding the survey of constructive anomalies, indicators (mathematical expressions) are used to reflect the degradation or loss of functional performance of the building's parts or aspects associated with maintenance. In relation to direct classification, the condition is expressed numerically (for example, on a scale of 0-100 points or in percentage) or in classes. One or both procedures can be implemented, whose selection depends on the purpose of BCA. Although the use of the constructive anomalies survey leads to more accurate BCA, the direct classification makes the evaluation of the building's parts faster;

- the building inspection consists of a survey carried out in loco in order to collect data that calculate the indicators or to evaluate the condition of all the parts of the building. In general, it is a visual observation made by expert inspectors (engineers or architects). Mayo and Karanja (2017) argue that BCA's accuracy is highly dependent on the experience and training of building inspectors. According to Straub (2009), the variability in the results obtained is due to the subjective perceptions of the inspectors. In order to accurately and reliably measure the building condition, Uzarski and Grussing (2008) argue that building inspection requires an objective and consistent process. Similarly, Dejaco, Cecconi and Maltese (2017) emphasise that the preparation and application of pre-formatted diagnostic forms for data collection make it possible to standardise the inspection process and avoid subjectivity. Ahluwalia (2008) reports the use of checklists or list of constructive anomalies in printed or electronic format, as well as the use of photos to register them;

- analysing the building conditions requires translating the data collected in the inspection into values. In the survey of constructive anomalies, the analysis comprises calculating a condition indicator (CI) for each part of the building. CIs can be aggregated to reflect the condition of higher levels in the hierarchy of the building's parts. In these combinations, the CIs are generally weighted to adequately represent the relative importance of each part concerning the safety and usability of the building or its participation in the cost (maintenance or replacement). In the direct classification of the condition, the analysis refers to the classification of the degradation state of the parts on ordinal scales (numerical or not).

Concerning periodicity, BCA is usually planned to occur based on a schedule, often one to five years. The literature review conducted by Ahluwalia (2008) pointed out the predominance for the implementation of BCA each year. Ahluwalia argues that long periods between inspections make the BCA more extensive and difficult, with an increase in its cost. Otherwise, Uzarski, Grussing and Clayton (2007) propose the periodicity based on the knowledge (measurable information) of the condition obtained in the previous inspection. In this case, the frequency and level of detail of the inspection are adjusted to the various stages of the life cycle of the building and its parts. The authors believe that this procedure results in a more efficient application of resources in BCA implementation.

There are several methods for BCA described in the literature that apply to different types of buildings. Dejaco, Cecconi and Maltese (2017) distinguished the main attributes required for the BCA. According to the authors, data collected in the inspection should be reliable and objective, as well as translated into one or more KPIs capable of facilitating the decision making of the building maintenance and prioritising the intervention.

The method for BCA proposed by Shohet (2003), which is the focus of this research, is presented next. 


\section{Building Performance Indicator (BPI)}

Shohet (2003) described the BPI as an indicator that allows the quantitative expression of the physical and functional condition of the building. The calculation of this indicator involves the performance evaluation of the various systems and elements that compose the building.

To begin with, the performance of the building systems $\left(\mathrm{P}_{n}\right)$ is evaluated combining three aspects of maintenance represented in the factors of Equation 1.

$\mathrm{P}_{\mathrm{n}}=\mathrm{C}_{\mathrm{n}} \times \mathrm{W}(\mathrm{c})_{n}+\mathrm{F}_{\mathrm{n}} \times \mathrm{W}(\mathrm{f})_{\mathrm{n}}+\mathrm{PM}_{\mathrm{n}} \times \mathrm{W}(\mathrm{pm})_{n}$

Where:

$\mathrm{C}_{n}$ is the factor that expresses the current physical and functional condition of each (n) system. The evaluation of each system occurs on an ordinal scale of five levels that are transformed into points ranging from 20 to 100 ;

$\mathrm{F}_{n}$ is the factor that reflects the frequency in which the failures affect the function of each $(n)$ system. The evaluation of each system also occurs in an ordinal scale of five levels transformed into points;

$\mathrm{PM}_{n}$ is the factor that represents the preventive maintenance activities performed in each ( $n$ ) system to keep it at an acceptable level of service. This factor is also expressed in the ordinal scale of five levels transformed into points. The preventive maintenance is evaluated considering the maintenance guidelines and the frequency of proactive inspections performed in each $(n)$ system;

$\mathrm{W}(\mathrm{c})_{n}, \mathrm{~W}(\mathrm{f})_{n}$ and $\mathrm{W}(\mathrm{pm})_{n}$ are the weights of the factors $\mathrm{C}_{n}, \mathrm{~F}_{n}$ and $\mathrm{PM}_{n}$, respectively, whose determination is based on the cost of failures and preventive maintenance. The sum of the weights must be equal to $\mathrm{W}(\mathrm{c})_{n}+$ $\mathrm{W}(\mathrm{f})_{n}+\mathrm{W}(\mathrm{pm})_{n}=1$ to each $(n)$ system.

Shohet (2003) proposes the evaluation of the current physical and functional condition for each element $\left(C_{n}\right)$ in five levels, expressed in scores varying from 20 to 100. For example, Table 1 refers to the criteria for the evaluation of the reinforced concrete columns that comprise the structural system of a building.] Table 2 presents the criteria for the assignment of the score to the factor $F_{n}$, which expresses the frequency of failures in building systems.

Table 3 illustrates the criteria associated with the frequency of the building inspections which are used for evaluating the preventive maintenance activities carried out in the systems $\left(\mathrm{PM}_{\mathrm{n}}\right)$.

Table 4 shows the distribution of the weights $\mathrm{W}(\mathrm{c})_{n}, \mathrm{~W}(\mathrm{f})_{n}$ and $\mathrm{W}(\mathrm{pm})_{n}$ for each building system for hospital buildings (SHOHET, 2003).

Table 1 - Scores and criteria for assessing the current condition $\left(C_{n}\right)$ of reinforced concrete columns

\begin{tabular}{|c|c|c|c|c|}
\hline $\begin{array}{c}\text { Dangerous } \\
\text { (20) }\end{array}$ & $\begin{array}{c}\text { Run-down } \\
(40)\end{array}$ & $\begin{array}{c}\text { Satisfactory } \\
(60)\end{array}$ & $\begin{array}{c}\text { Good } \\
(\mathbf{8 0})\end{array}$ & $\begin{array}{c}\text { Very good } \\
(100)\end{array}$ \\
\hline $\begin{array}{l}\text { Existence of diagonal } \\
\text { cracks more than } 0.5 \\
\text { mm wide crossing the } \\
\text { section of the } \\
\text { column, or } \\
\text { fracture/buckling of } \\
\text { concrete has already } \\
\text { taken place. }\end{array}$ & $\begin{array}{l}\text { Existence of } \\
\text { diagonal cracks up } \\
\text { to } 0.5 \mathrm{~mm} \text { wide } \\
\text { crossing the } \\
\text { section. Shedding } \\
\text { of concrete has } \\
\text { begun, exposing the } \\
\text { reinforcement. }\end{array}$ & $\begin{array}{l}\text { Existence of } \\
\text { vertical cracks } \\
\text { due to corrosion } \\
\text { of reinforcement } \\
\text { bars in isolated } \\
\text { locations. }\end{array}$ & $\begin{array}{l}\text { Localised hair- } \\
\text { cracks } \\
\text { discernible here } \\
\text { and there, but no } \\
\text { signs of } \\
\text { corrosion. }\end{array}$ & $\begin{array}{l}\text { No cracks and no } \\
\text { sign of corrosion } \\
\text { whatsoever. }\end{array}$ \\
\hline
\end{tabular}

Source: Shohet (2003).

Table 2 - Scores and criteria for assessing the frequency of failures $\left(F_{n}\right)$

\begin{tabular}{c|c|c|c|c}
\hline $\mathbf{( 2 0 )}$ & $\mathbf{( 4 0 )}$ & $\mathbf{( 6 0 )}$ & $\mathbf{( 8 0 )}$ & $\mathbf{( 1 0 0 )}$ \\
\hline $\begin{array}{c}12 \text { times a year, } \\
\text { or more. }\end{array}$ & $6-11$ times a year. & $2-5$ times a year. & Once a year. & $\begin{array}{c}\text { Less than once a } \\
\text { year. }\end{array}$ \\
\hline
\end{tabular}

Source: adapted from Shohet (2003). 
Table 3 - Scores and criteria for assessing the frequency of building inspections $\left(\mathbf{P M}_{\mathrm{n}}\right)$

\begin{tabular}{c|c|c|c|c}
\hline $\mathbf{( 2 0 )}$ & $\mathbf{( 4 0 )}$ & $\mathbf{( 6 0 )}$ & $\mathbf{( 8 0 )}$ & $\mathbf{( 1 0 0 )}$ \\
\hline Never. & $\begin{array}{c}\text { Every two years, } \\
\text { or less frequently. }\end{array}$ & Annually. & Semi-annually. & $\begin{array}{c}\text { Quarterly (once every } \\
\text { three months). }\end{array}$ \\
\hline
\end{tabular}

Source: adapted from Shohet (2003).

Table 4 - Distribution of the weights (\%) for each building system (n) in the $\mathbf{P}_{\mathbf{n}}$ score for hospital building systems

\begin{tabular}{l|c|c}
\hline \multicolumn{1}{c|}{ Building system } & $\begin{array}{c}\text { Weight of physical performance } \\
\text { and frequency of failures } \\
\mathbf{( \% )}\end{array}$ & $\begin{array}{c}\text { Weight of periodical } \\
\text { maintenance } \\
\text { (\%) }\end{array}$ \\
\hline Structure & 90 & 10 \\
Interior finishing & 70 & 30 \\
Exterior envelope & 75 & 25 \\
Fire protection & 75 & 25 \\
Water and wastewater & 75 & 25 \\
Elevators & 60 & 40 \\
Electrical system & 50 & 50 \\
Communications & 50 & 50 \\
HVAC & 50 & 50 \\
Medical Gases & 20 & 80 \\
\hline
\end{tabular}

Source: Shohet (2003).

Shohet (2003) comments that the weight of 90\% attributed to the physical performance and frequency of failures reflects the low cost of preventive maintenance (periodic visual inspections) compared to the implications of failures in its constructive elements.

The validation of the proposed scales for the factors in Tables 1 to 3 was carried out through a group of 14 building inspectors, who received previous training to evaluate the same building. According to Shohet (2003), there was low variability in the assessment among the inspectors. However, the author highlights the need for in-depth training of inspectors regarding the application of these scales.

Next, BPI is obtained by applying Equation 2.

BPI $=\sum_{\mathrm{n}} \mathrm{P}_{\mathrm{n}} \times \mathrm{W}_{\mathrm{n}}$

Where:

$\mathrm{P}_{n}$ refers to the performance level for each $(n)$ system on a 100-point scale; and

$\mathrm{W}_{n}$ is the weight, in percentage, of the $(n)$ system.

The weight $\left(\mathrm{W}_{\mathrm{n}}\right)$ is obtained through the contribution of each $(n)$ system to the life cycle cost (LCC) of the building, which reflects the essence of the building management operations.

The BPI value reflects the performance level of the entire building. It is classified by Shohet (2003) in:

(a) BPI $>80$ indicates good or better conditions;

(b) $70<\mathrm{BPI} \leq 80$ shows that some of the building systems are in a marginal condition, requiring some preventive maintenance measures;

(c) $60<\mathrm{BPI} \leq 70$ expresses the deteriorated condition of the building, requiring the use of corrective and preventive activities; and

(d) $\mathrm{BPI} \leq 60$ means that the building is run-down.

The BPI implementation in several hospital complexes in Israel was reported by Shohet (2003), Shohet, LavyLeibovich and Bar-On (2003), Shohet and Lavy (2004b) and Lavy and Shohet (2004). The results and analyses of the BPI in this application were presented to six facility managers with experience in maintenance. Managers were asked to evaluate the accuracy and reliability of the BPI with responses on a five-point scale, where 1 indicates completely inaccurate and 5 represents highly accurate. The mean of responses equal to 4.17 
(standard deviation of 0.65) was considered high, showing a good level of accuracy. This BPI validation, among other KPIs for the management of building maintenance, was described by Lavy and Shohet (2004).

In summary, BPI evaluates the physical and functional condition of the building and its parts based on performance and economic criteria. Shohet (2006) points out four contributions to the application of BPI:

(a) the assessment of the overall condition of the building;

(b) the assessment of the condition of its various constructive systems and elements; and

(c) the comparative analysis of building performance in relation to other buildings (intra-organisational benchmarking) or between facilities (inter-organisational benchmarking).

Due to these contributions, BPI can be applied to define the organisational strategy in terms of performance requirements and for decision making at the tactical level.

Although the focus of BPI application has been on public hospital facilities, Lavy and Shohet (2004) argue that the indicator can be implemented for the assessment of other types of buildings, since it is modified according to the constructive characteristics.

\section{Research method}

The stages of the research consisted of:

(a) adjusting the factors and criteria that comprise BPI;

(b) implementing two recurrent constructive typologies on a university campus; and

(c) verifying its utility and ease of use.

Two recurrent constructive typologies of the University X campus were selected:

(a) building intended for classrooms; and

(b) building for teaching and research laboratory.

\section{Adjustment of BPI}

Initially the two selected buildings were decomposed into constructive systems and subsystems taking into account:

(a) the function; and

(b) the interaction of the degradation mechanisms that lead to the loss of physical performance, following the criteria proposed by Rodrigues (2001) to identify the elements subject to maintenance (ESM).

The weights $\mathrm{W}(\mathrm{c})_{n}, \mathrm{~W}(\mathrm{f})_{n}$ and $\mathrm{W}(\mathrm{pm})_{n}$ of the $\mathrm{P}_{\mathrm{n}}$ factors were also established according to the distributions of Shohet (2003), shown in Table 1 adapting them to the systems of the buildings of this study.

In order to calculate BPI, weight $\mathrm{W}_{n}$ was obtained by the relation between the Life Cycle Cost (LCC) of each system and of the building, expressed in percentage. The costs involved in an LCC analysis are usually grouped by categories and phases of the life cycle of the building. They were structured according to the ISO 15686-5 (INTERNATIONAL..., 2017) as:

(a) the initial construction cost;

(b) maintenance-related cost required to ensure functional performance covering corrective, preventive maintenance and replacement activities; and

(c) the resale value of the building.

The simplified calculation model adopted is presented in Equation 3. It was adapted from E917-17 (AMERICAN..., 2017).

PVLCC $=$ IC + PVM - PVS

Where:

PVLCC is the net present value ( $\mathrm{R} \$)$;

IC is the initial cost ( $R \$)$; 
PVM is the present value of maintenance and repair cost (R\$); and

PVS is the present value of resale value $(\mathrm{R} \$)$.

The Initial Cost (IC) corresponded to the sum of the construction costs estimated for each part of the building, resulting in the total cost. A margin of $30 \%$ was added to this total cost.

Maintenance and repair cost $(\mathrm{M})$ over the service life was calculated based on the maintenance records collected by the researchers according to the construction typologies. These data describe corrective, preventive and component maintenance activities and also the periodicity of these activities. The maintenance interventions considered the history of these maintenance interventions, the current physical condition and the maintenance plans developed for similar buildings. The cost of the maintenance interventions was calculated based on the unit parameters for maintenance services extracted from specialised publications and the prices were obtained from the local market. A margin of 30\% was added to this cost of maintenance interventions.

In the LCC analysis, the resale value (S) covers the costs of demolition, removal of debris and cleaning of the site. According to Lopes and Alonso (2007), this cost has been assumed equal to $20 \%$ of the initial cost.

All relevant cost components were discounted to a common time in a cash flow in period $t=0$ to $\mathrm{N}$. The calculation was given in terms of the net present value as represented in Equation 4, according to ASTM E91717 (AMERICAN..., 2017).

PVLCC $=\sum_{\mathrm{t}=0}^{\mathrm{N}} \frac{\mathrm{C}_{\mathrm{t}}}{(1+\mathrm{i})^{\mathrm{t}}}$

Where:

PVLCC is the Net Present Value of the cash flow (R\$);

$\mathrm{C}_{\mathrm{t}}$ is the sum of all relevant costs occurring in $(t)$ year $(\mathrm{R} \$)$;

$\mathrm{N}$ is the length of the study period (year); and

$\mathrm{i}$ is the discount rate (\%).

The period of analysis ( $\mathrm{N}$ ) of the LCC usually refers to the predicted occupancy period of the building (life cycle). In this work, it was adopted equally to 50 years since very long periods also distort the influence of activities very far from the start time.

The discount rate (i), as a technique used to compare costs that occur in different periods of time, was assumed equal to $3.5 \%$ per annum, reflecting the real discount rate that excludes inflation. Such a rate is regularly used in the analysis of public projects in the United Kingdom (HM TREASURY, 2018). This rate is also used by Marenjak, El-Haram and Horner (2003) and it is within the range, 3-4\% per annum used in European countries (DAVIS..., 2007).

The LCC analysis for both buildings was conducted using the Microsoft Excel ${ }^{\circledR}$ spreadsheet, allowing the calculation of $\left(\mathrm{W}_{\mathrm{n}}\right)$ weights that comprise the BPI indicator.

\section{Implementation of the adapted BPI}

The implementation phase aimed at demonstrating the utility and ease of use of the adapted BPI. The two selected buildings were inspected following the procedures established in the Brazilian Building Inspection Standard (INSTITUTO..., 2012). The inspections of the buildings were visually carried out by one inspector who works at University $\mathrm{X}$ and has a degree in civil engineering. This inspector is a faculty member and has been working in engineering, building inspection and maintenance of buildings since 1993.

Inspection led to assigning scores to factor $C_{n}$ of the system's components. The assigned scores to factors $F_{n}$ and $\mathrm{PM}_{n}$ were based on prior knowledge of the interventions carried out by the building maintenance department of the university. Thus, the $\mathrm{P}_{\mathrm{n}}$ for each system of the building was obtained considering weights $\mathrm{W}(\mathrm{c})_{n}, \mathrm{~W}(\mathrm{f})_{n}$ and $\mathrm{W}(\mathrm{pm})_{n}$.

Finally, the BPI indicator was calculated for each building in order to quantitatively express its condition.

\section{Verification of utility and ease of use of the adapted BPI}

The implementation of the adapted BPI was verified taking into account the utility and ease of use of the indicator. Empirical evidence was established in terms of what the BCA's content should be and how its process should be. 
Regarding the utility for the building maintenance management, the observed variables are associated with three requirements: identifying the construction systems that need more attention; identifying the overall state of the building in order to prioritise maintenance intervention; and indicating the most appropriate maintenance strategy. The sources of evidence were the results obtained for the condition $\left(\mathrm{P}_{\mathrm{n}}\right)$ of each system and the BPI of the building. Data for this evidence came from the inspection report provided by the inspector.

Considering the ease of use, the observed variable is associated with the speed of assessment, measured by the time (h) spent by the inspector. The source of evidence is the record of the beginning and end of work registered by the inspector in his inspection report.

\section{Results and discussion}

\section{Characterisation of the buildings selected for the study}

The two buildings are located on the campus of University X. The first building is intended for classrooms, called the Classroom Centre, as shown in Figure 1.

The Classroom Centre was built in 2013, comprising 3.236,65 $\mathrm{m}^{2}$ distributed on three floors: open ground floor and the two upper floors that have 16 classrooms. The building also has the main stairwell, and toilets, as well as another emergency staircase.

The constructive system used in this building consists of a cast-in-place concrete structure, exterior walls of masonry with ceramic blocks and internal walls with plasterboard plates. Regarding roofing, it is made in a metallic structure and galvalume steel tiles, with internal thermoacoustic protection in EPS. Aluminium and wood are the materials chosen, respectively, for windows and doors. The coating of external walls is made with mortar, ceramic on the outside of the stairwell and ceramic tiles on the internal face of the toilets. The ceiling is coated with mortar, except for the toilets, which were made out of PVC. The inner face of the walls was painted with latex paint, and the outer face with acrylic paint. The floor is made from concrete and the electrical system and hydraulic installations can be found inside it.

The second building is intended for the Materials Laboratory, as illustrated in Figure 2.

Figure 1 - North facade of the Classroom Centre

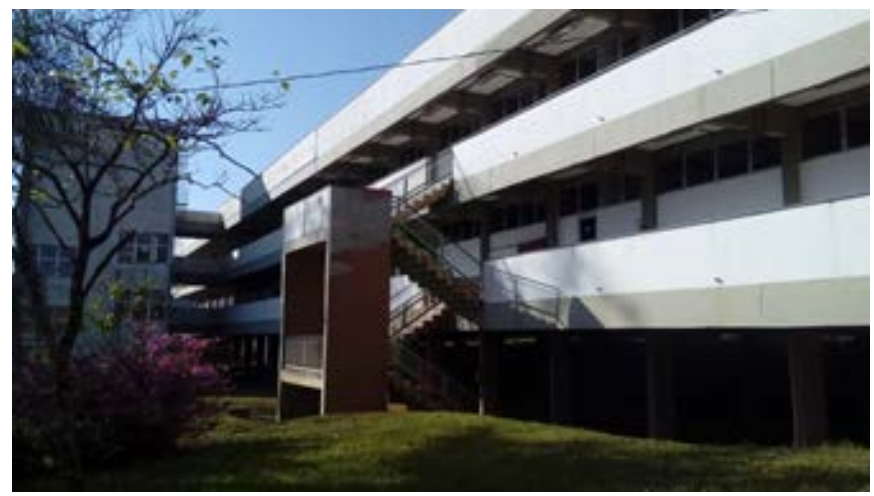

Figure 2 - East facade of the Building Materials Laboratory

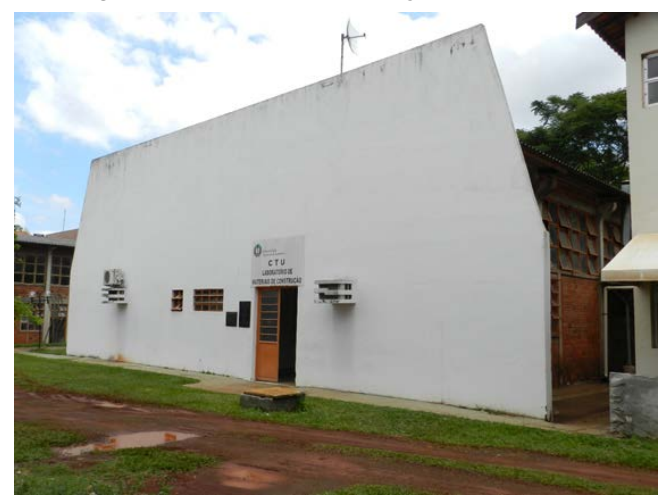


The Building Materials Laboratory was built in 1994, containing $42000 \mathrm{~m}^{2}$ and houses the laboratory experiment room, classroom, office, storage room and wet chamber. The constructive system used consists of a precast concrete structure, except the north and south facade with a cast-in-place concrete structure. The internal and external walls were made in ceramic block masonry. The roof was built in prefabricated concrete beams and fibre cement sheets, and the windows and doors are made of steel. The coating of the walls is mortar and they are painted with latex paint on the inner face and with acrylic paint on the outer face. The floor is made out of cement. The system and hydraulic installations can be found inside the walls and floors.

\section{Identifying the construction systems ( $\mathrm{n}$ )}

The two university buildings were decomposed into six systems, which in turn were grouped into subsystems and elements as listed in Table 5.

The parts of the building hierarchically presented in Table 5 made it possible to survey the life cycle cost in the level of each element subject to maintenance (ESM).

\section{Definition of the Weights W(c)n, W(f)n and W(pm)n to obtain Pn}

For the purpose of calculating $\mathrm{P}_{\mathrm{n}}$, the relative importance of the physical condition, frequency of failures and periodic maintenance was considered, expressed in Table 4 . The weights adopted for $\mathrm{W}(\mathrm{c})_{n}, \mathrm{~W}(\mathrm{f})_{n}$ and $\mathrm{W}(\mathrm{pm})_{n}$ are given in Table 6.

\section{LCC analysis}

The Initial Cost of the two buildings was calculated based on the quantification of construction services and taking into account the unit cost published by the National System of Costs Survey and Civil Construction Indices (SINAPI) for the state of Paraná, Brazil. The data collection period of the unit cost in SINAPI was August 2016 for the Classroom Centre and October 2017 for the Building Materials Laboratory (CAIXA..., 2016, 2017). A margin of 30\% was added and the results are presented in Table 7.

In the LCC analysis, the maintenance cost (M) should comprise the corrective, preventive and replacement activities, and also their frequencies during the life cycle. These costs must be for each ESM and, particularly considered the constructive system, the exposure characteristics and the use of the building under analysis. In this study, maintenance records were calculated for each ESM that composes the buildings. An example of the maintenance cost (M) for the facade cladding of the Classroom Centre is presented in Table 8.

Table 5 - Breakdown of university building in systems and subsystems

\begin{tabular}{|c|c|c|}
\hline $\mathbf{n}$ & Building system & Building subsystem \\
\hline \multirow{2}{*}{1} & \multirow{2}{*}{ Structure } & Foundation \\
\hline & & Superstructure \\
\hline \multirow{3}{*}{2} & \multirow{3}{*}{ Roof } & Roof structural frame \\
\hline & & Fibre cement roof sheet \\
\hline & & Gutter \\
\hline \multirow{3}{*}{3} & \multirow{3}{*}{ Exterior enclosure } & Wall \\
\hline & & Wall finishes \\
\hline & & Windows and doors \\
\hline \multirow{6}{*}{4} & \multirow{6}{*}{ Interior construction } & Wall and partitions \\
\hline & & Wall finishes \\
\hline & & Ceiling finishes \\
\hline & & Floor finishes \\
\hline & & Doors \\
\hline & & Balustrades and screens \\
\hline \multirow{3}{*}{5} & \multirow{3}{*}{ Hydraulic installations } & Water and waste water \\
\hline & & Rain water drainage \\
\hline & & Fire protection \\
\hline \multirow{3}{*}{6} & \multirow{3}{*}{ Electrical system } & Lighting and branch wiring \\
\hline & & IT networks \\
\hline & & Lightning strike protection \\
\hline
\end{tabular}


Table 6 - Distribution of the weight (\%) of factors that compose $\mathbf{P}_{\mathbf{n}}$

\begin{tabular}{l|l|c|c|c}
\hline \multirow{2}{*}{$\mathbf{n}$} & \multirow{2}{*}{ Building system } & \multicolumn{3}{|c}{$\begin{array}{c}\text { Weight } \\
\text { (\%) }\end{array}$} \\
\cline { 3 - 5 } & & W(c) & W(f) & W(pm) \\
\hline 1 & Structure & 72 & 18 & 10 \\
2 & Roof & 60 & 15 & 25 \\
3 & Exterior enclosure & 60 & 15 & 25 \\
4 & Interior construction & 56 & 14 & 30 \\
5 & Hydraulic installations & 60 & 15 & 25 \\
6 & Electrical system & 40 & 10 & 50 \\
\hline
\end{tabular}

Table 7 - Initial cost of construction per system ( $\mathbf{n}$ ) for university buildings

\begin{tabular}{l|l|r|r}
\hline \multirow{2}{*}{$\mathbf{n}$} & \multirow{2}{*}{ Building system } & \multicolumn{2}{|c}{ Initial cost (US\$) } \\
\cline { 3 - 4 } & & Classroom Centre & Building Materials Laboratory \\
\hline 1 & Structure & $394,337.26$ & $32,487.78$ \\
2 & Roof & $51,316.19$ & $18,206.04$ \\
3 & Exterior enclosure & $242,746.09$ & $42,714.93$ \\
4 & Interior construction & $170,553.79$ & $22,078.51$ \\
5 & Hydraulic & $43,683.84$ & $1,070.31$ \\
& installations & $118,472.77$ & $10,217.76$ \\
\hline & Electrical system & $\mathbf{1 , 0 2 1 , 1 0 9 . 9 4}$ & $\mathbf{1 2 6 , 7 7 5 . 3 2}$ \\
\hline
\end{tabular}

Table 8 - Example of the maintenance record developed for the exterior wall finish

\begin{tabular}{|c|c|c|c|c|}
\hline \multicolumn{2}{|l|}{ Subsystem } & \multicolumn{3}{|l|}{ Wall finishes } \\
\hline \multicolumn{2}{|l|}{ Element } & \multicolumn{3}{|l|}{ Ceramic plates } \\
\hline \multicolumn{2}{|l|}{ Initial cost ( $R \$)$} & & & $39,287.34$ \\
\hline $\begin{array}{c}\text { Maintenance } \\
\text { level }\end{array}$ & $\begin{array}{c}\text { Periodicity } \\
\text { (year) }\end{array}$ & Building maintenance service & $\begin{array}{c}\text { Ratio } \\
(\%)\end{array}$ & $\begin{array}{c}\text { Maintenance } \\
\text { cost (US\$) } \\
\end{array}$ \\
\hline $\begin{array}{l}\text { A - Inspection } \\
\text { of control }\end{array}$ & 3 & Check for detachments. & 0.1 & 39.29 \\
\hline $\begin{array}{l}\text { B - Preventive } \\
\text { cleaning and/or } \\
\text { treatment }\end{array}$ & 3 & Cleaning of localised stains and dirt. & 1.3 & 510.73 \\
\hline $\begin{array}{l}\mathrm{C} \text { - Small } \\
\text { interventions }\end{array}$ & 10 & $\begin{array}{l}\text { Painting ( } 100 \% \text { of paint area): } \\
\text { application of waterproofing. } \\
\text { Repair ( } 5 \% \text { of area): detachments. } \\
\text { Repair }(10 \% \text { of area): degraded } \\
\text { grouting. }\end{array}$ & 13.0 & $5,107.35$ \\
\hline $\begin{array}{l}\text { D - Major } \\
\text { intervention }\end{array}$ & - & - & 0.0 & 0.00 \\
\hline E - Replacement & - & - & 0.0 & 0.00 \\
\hline
\end{tabular}

Bromilow and Pawsey (1987) recommend that the appropriate procedure for inferring future needs is to review archived information regarding buildings in the past. However, it is generally found that there is no archived data. Taking such a prospect into consideration, the indication of the maintenance services should be based on different sources of consultation. Such sources would be the building preventive maintenance plan prepared by the Secretary of Maintenance of the Court of Justice of the Federal District and Territories (TRIBUNAL..., 2013), the building management manual developed by the Administration Secretariat of the State of Bahia (BAHIA, 2009), the building maintenance manual produced by the State Secretariat for Administration and the Patrimony of the Federal Government (BRASIL, 1997), as well as in the records developed by the Catalonia Institute of Construction Technology (INSTITUT..., 1991a, 1991b, 1991c) and Albano (2005). 
The maintenance activities were categorised in five levels:

(a) inspection of control, in which the manager seeks to identify the occurrence of constructive failures;

(b) preventive cleaning and/or treatment, whose activities are aimed at the removal of debris, dirt or obstructions;

(c) small interventions;

(d) major intervention; and

(e) replacement, completely removing most of the elements and constructive components and applying new ones.

The cost of the maintenance activities was determined from the quantitative estimate necessary to preserve or recover the functional capacity of each ESM due to the current occurrence of constructive failures. The cost of these activities was established on the basis of the services' costs published in SINAPI. Table 8 shows an example of cladding with ceramic plates.

As a result, maintenance costs $(\mathrm{M})$ were calculated over the period of analysis for the Classroom Centre and the Building Materials Laboratory.

Finally, the residual value (S) of each $(n)$ system of the building was estimated.

The results of the LCC analysis for the Classroom Centre and Building Materials Laboratory are presented in Appendices A and B, respectively.

It should be noted that the distribution of maintenance cost $(\mathrm{M})$ over the period of analysis made it possible to estimate the average annual maintenance cost of US\$ 15,506.85/year and US\$ 7,028.95/year for the Classroom Centre and the Laboratory, respectively. The relation of these maintenance costs to the IC corresponded to $1.5 \%$ and 5.5\%. The indices (M/IC) obtained are close to those reported by Abate et al. (2009), of 1.72\% and $2.98 \%$ for buildings of similar use.

\section{Determination of weights $\mathrm{W}_{\mathbf{n}}$ for the calculation of BPI}

The last column of tables in Appendices A and B shows the participation (\%) of each $(n)$ constructive system in the LCC analysis, which is equivalent to the weights $\left(\mathrm{W}_{\mathrm{n}}\right)$ to obtain the BPI as listed in Table 9.

The weight $\left(\mathrm{W}_{\mathrm{n}}\right)$ also reveals the preponderance of each $(n)$ system from the perspective of the overall cost, which makes it possible to focus on the building maintenance management in terms of expenses. As can be seen in Table 9, the systems structure (31\%) and sealing and interior finishing (25\%) predominate for the Classroom Centre, while for the Building Materials Laboratory the systems roof (31\%), and facade (28\%) prevail.

\section{Implementing the adapted BPI}

The Classroom Centre and Building Materials Laboratory were inspected by the inspector. All inspections were carried out over the same period.

A spreadsheet was used to record the scores assigned by the inspector to factor $C_{n}$. In order to assign the scores to factors $\mathrm{F}_{n}$ and $\mathrm{PM}_{n}$, the maintenance occurrences in the buildings and the inspection activities carried out by Facilities Services of University X were analysed.

The scores to $\mathrm{C}_{n}, \mathrm{~F}_{n}$ and $\mathrm{PM}_{n}$ allowed the calculation of $\mathrm{P}_{\mathrm{n}}$, considering the weight of each factor (Table 6) and applying Equation 1. Finally, they enabled the calculation of the BPI for the building, taking into account the participation of each system (Table 9) and using Equation 2.

As an example, Table 10 summarises the condition assessment of the Classroom Centre performed by the inspector. 
Table 9 - Weights $\left(\mathbf{W}_{\mathbf{n}}\right)$ of BPI for the investigated buildings

\begin{tabular}{c|l|c|c}
\hline \multirow{2}{*}{$\mathbf{n}$} & \multirow{2}{*}{ Building system } & \multicolumn{2}{|c}{$\begin{array}{c}\mathbf{W}_{\mathbf{n}} \\
\text { (\%) }\end{array}$} \\
\cline { 3 - 4 } & & Classroom Centre & Building Materials Laboratory \\
\hline 1 & Structure & 31 & 20 \\
2 & Roof & 5 & 31 \\
3 & Exterior enclosure & 18 & 28 \\
4 & Interior construction & 25 & 14 \\
5 & Hydraulic installations & 7 & 1 \\
6 & Electrical system & 14 & 6 \\
\hline
\end{tabular}

Table 10 - Condition assessment of the Classroom Centre by the inspector

\begin{tabular}{|c|c|c|c|c|c|c|c|c|c|c|}
\hline \multirow[t]{2}{*}{$\mathbf{n}$} & \multirow[t]{2}{*}{ Building system } & \multicolumn{2}{|c|}{$\begin{array}{c}\text { Actual } \\
\text { condition of } \\
\text { the system }\end{array}$} & \multicolumn{2}{|c|}{$\begin{array}{c}\text { Failures } \\
\text { affecting the } \\
\text { service } \\
\text { provided by } \\
\text { the system }\end{array}$} & \multicolumn{2}{|c|}{$\begin{array}{l}\text { Preventive } \\
\text { activities } \\
\text { carried out in } \\
\text { the system }\end{array}$} & \multirow[t]{2}{*}{$\mathbf{P}_{\mathbf{n}}$} & \multirow[t]{2}{*}{$\begin{array}{l}W_{n} \\
(\%)\end{array}$} & \multirow[t]{2}{*}{$\mathbf{P}_{\mathbf{n}} \times \mathbf{W}_{\mathbf{n}}$} \\
\hline & & $\mathbf{C}_{\mathbf{n}}$ & $\begin{array}{l}W C_{n} \\
(\%)\end{array}$ & $\mathbf{F}_{\mathbf{n}}$ & $\begin{array}{l}\text { WFn } \\
(\%)\end{array}$ & $\mathbf{P M}_{\mathbf{n}}$ & $\begin{array}{c}\text { WPMn } \\
(\%)\end{array}$ & & & \\
\hline 1 & Structure & 100 & 72 & 100 & 18 & 20 & 10 & 92 & 31 & 28.5 \\
\hline 2 & Roof & 100 & 60 & 100 & 15 & 20 & 25 & 80 & 5 & 4.0 \\
\hline 3 & Exterior enclosure & 80 & 60 & 60 & 15 & 20 & 25 & 62 & 18 & 11.2 \\
\hline 4 & Interior construction & 80 & 56 & 80 & 14 & 20 & 30 & 62 & 25 & 15.5 \\
\hline 5 & Hydraulic installations & 100 & 60 & 80 & 15 & 20 & 25 & 77 & 7 & 5.4 \\
\hline 6 & Electrical system & 100 & 40 & 80 & 10 & 20 & 50 & 58 & 14 & 8.1 \\
\hline & & & & & & & & & $\mathbf{B P I}=$ & 73 \\
\hline
\end{tabular}

The scores attributed by the inspector (Table 10) revealed the good physical and functional condition for the structural (92) and roof (80) systems of the Classroom Centre, while the electrical system is in a worse condition (58). Regarding the overall condition of the building, the BPI equal to 73 indicates that this building has some of its systems in a marginal condition of performance, requiring some preventive maintenance measures.

Table 11 summarises the scores assigned in the condition assessment of the Building Materials Laboratory by the inspector.

For the Building Materials Laboratory, the scores given by the inspector in Table 11 pointed out only the structural system in good physical and functional conditions (82), while the roof was in a worse condition (45). The BPI equal to 60 expressed the deteriorated overall condition of the Building Materials Laboratory, indicating the need to use corrective activities to recover and maintain it under satisfactory conditions.

\section{Verifying the utility and ease of use of the adapted BPI}

The utility of the adapted BPI was verified based on the results obtained for $\mathrm{P}_{\mathrm{n}}$ and BPI, which are recorded in the reports issued by the inspector.

The decomposition of the building adopted in BPI identified the building systems that deserve more attention by the building maintenance manager, such as the electrical installations $\left(P_{n}=58\right)$ for the Classroom Centre and the roofing $\left(\mathrm{P}_{\mathrm{n}}=45\right)$ for the Laboratory.

The comparison of the results obtained for BPI between the buildings indicated the Laboratory $(\mathrm{BPI}=60)$ in a more degraded condition than the Classroom Centre (BPI = 73). Therefore, the BPI allowed the building maintenance manager to establish the priority of intervention in those buildings. In addition, the most adequate maintenance strategy was defined to keep them in a satisfactory state.

In the performance assessment of the systems, numerical criteria and scales were adopted, which made standardisation of the measurement procedure possible. However, the dispersion of the results obtained for $P_{n}$ and, consequently, for BPI was observed. 
Table 11 - Condition assessment of the Building Materials Laboratory by the inspector

\begin{tabular}{|c|c|c|c|c|c|c|c|c|c|c|}
\hline \multirow[t]{2}{*}{$\mathbf{n}$} & \multirow[t]{2}{*}{ Building system } & \multicolumn{2}{|c|}{$\begin{array}{l}\text { Actual } \\
\text { condition of } \\
\text { the system }\end{array}$} & \multicolumn{2}{|c|}{$\begin{array}{c}\text { Failures } \\
\text { affecting the } \\
\text { service } \\
\text { provided by } \\
\text { the system }\end{array}$} & \multicolumn{2}{|c|}{$\begin{array}{l}\text { Preventive } \\
\text { activities } \\
\text { carried out in } \\
\text { the system }\end{array}$} & \multirow[t]{2}{*}{$\mathbf{P}_{\mathbf{n}}$} & \multirow[t]{2}{*}{$\begin{array}{c}W_{n} \\
(\%)\end{array}$} & \multirow[t]{2}{*}{$P_{n} \times W_{n}$} \\
\hline & & $\mathbf{C}_{\mathbf{n}}$ & $\begin{array}{l}W C_{n} \\
(\%)\end{array}$ & $\mathbf{F}_{\mathbf{n}}$ & $\begin{array}{l}\text { WF } \\
\text { (\%) }\end{array}$ & $\mathbf{P M}_{\mathbf{n}}$ & $\begin{array}{c}\text { WPM }_{n} \\
(\%)\end{array}$ & & & \\
\hline 1 & Structure & 80 & 72 & 100 & 18 & 60 & 10 & 82 & 20 & 16.3 \\
\hline 2 & Roof & 40 & 60 & 40 & 15 & 60 & 25 & 45 & 31 & 14.0 \\
\hline 3 & Exterior enclosure & 60 & 60 & 60 & 15 & 60 & 25 & 60 & 28 & 16.8 \\
\hline 4 & Interior construction & 60 & 56 & 80 & 14 & 60 & 30 & 63 & 14 & 8.8 \\
\hline 5 & Hydraulic installations & 80 & 60 & 80 & 15 & 60 & 25 & 75 & 1 & 0.8 \\
\hline 6 & Electrical system & 60 & 40 & 60 & 10 & 60 & 50 & 60 & 6 & 3.6 \\
\hline
\end{tabular}

Regarding ease of use, the time (h) spent on applying the adapted BPI was 3 hours for the Classroom Centre and 45 minutes for the Laboratory. Consequently, the speed and the feasibility were verified when implementing the building inspection in the application of BPI.

It was realised that such advantages resulted from the only visual observation of the condition of the building systems performed by a single professional. Furthermore, the data related to the frequency of constructive failures and the occurrence of preventive maintenance activities were also easily accessed by the organisation responsible for the building maintenance. Thus, the reduction in the cost of building inspection is possible.

\section{Conclusion}

Shohet and Lavy (2004a) define the maintenance of buildings comprising the activities that continuously ensure the usability of the building in a cost-effective way for a certain level of performance. In this sense, they affirm that the definition strongly connects the maintenance of buildings with the functional performance and the cost of the interventions.

In close accordance with this, the BPI indicator proposed by Shohet (2003) is based on using systematic classification scales for assessing the physical and functional condition of the whole building and its systems. In addition, BPI is weighted by an economic aspect since the weights $\left(\mathrm{W}_{\mathrm{n}}\right)$ are derived from an LCC analysis. This means that BPI establishes a relationship between the physical condition of each system and the economic aspects of building maintenance.

BPI as a method for assessing the building condition proved to be easy to apply and inexpensive since it consumed a small workload from a single inspector for visual observation and judgment of the condition. Moreover, the adoption of standardised criteria and scale of measurement contributes to minimising the subjectivity in the judgment of the condition of the systems and, consequently, of the building.

The methodology for composing BPI is generic and could be implemented in the two university buildings under study. Nevertheless, its adjustment, done by the LCC analysis, required the specification of the maintenance activities, their periodicities and costs, which demands data and information, in general, not stored by the organisms responsible for building maintenance.

The study showed that the BPI indicator makes it possible to determine maintenance intervention priorities based on the overall performance of the building and in each of its systems. Moreover, it was found to be a tool that helps decision making, at the strategic level, for building maintenance management of a university campus.

\section{References}

ABATE, D. et al. The Whitestone facility maintenance and repair cost reference 2009-2010. $14^{\text {th }}$ ed. Santa Barbara: Whitestone Research, 2009. 
ABBOTT, G. R. et al. Building condition assessment: a performance evaluation tool towards sustainable asset management. In: CIB WORLD BUILDING CONGRESS, Cape Town, 2007. Proceedings [...] Cape Town, 2007.

AHLUWALIA, S. S. A framework for efficient condition assessment of the building insfrastructure. Waterloo, 2008. 160 f. Tese (Doutorado em Engenharia Civil) - University of Waterloo, Ontario, 2008.

ALBANO, J. Maintenance des bâtiments em 250 fiches pratiques. 2 ed. Paris: Le Moniteur Editions, 2005.

AMERICAN SOCIETY FOR TESTING AND MATERIALS. E917-17: standard practice for measuring life-cycle costs of buildings and building systems. West Conshohocken, 2017.

AMERICAN SOCIETY OF CIVIL ENGINEERS. ASCE/SEI 30-14: guideline for condition assessment of the building envelope. Reston, 2014.

BAHIA. Manual de gestão predial. Salvador: Secretaria de Administração, 2009.

BOLDO, P. Avaliação quantitativa de estruturas de concreto armado de edificações no âmbito do Exército Brasileiro. Brasília, 2002. 295 f. Dissertação (Mestrado em Engenharia Civil), Faculdade de Tecnologia da Universidade de Brasília, Brasilia, 2002.

BRASIL. Ministério do Planejamento, Orçamento e Gestão. Secretaria de Estado da Administração e Patrimônio. Manual de obras públicas - edificações - manutenção. práticas da SEAP. Brasília: SEAP, 1997.

BROMILOW, F. J.; PAWSEY, M. R. Life cycle cost of university buildings. Construction Management and Economics, v. 5, p. 3-22, 1987.

CAIXA ECONÔMICA FEDERAL. Sistema Nacional de Pesquisa de Custos e Índices da Construção Civil. PCI.817.01 - custo de composições: sintético. Data de emissão: 18/08/2016. Brasília, 2016. Disponível em: http://www.caixa.gov.br/poder-publico/apoio-poder-publico/sinapi. Acesso em: 15 out. 2019.

CAIXA ECONÔMICA FEDERAL. Sistema Nacional de Pesquisa de Custos e Índices da Construção Civil. PCI.817.01 - custo de composições - sintético. Data de emissão: 11/10/2017. Brasília, 2017. Disponível em: http://www.caixa.gov.br/poder-publico/apoio-poder-publico/sinapi. Acesso em: 15 out. 2019.

CASTRO, E. D. Desenvolvimento de metodologia para manutenção de estruturas de concreto armado. Brasília, 1994. Dissertação (Mestrado em Engenharia Civil) - Faculdade de Tecnologia, Universidade de Brasília, Brasília, 1994.

DAVIS LANGDON MANAGEMENT CONSULTING. Life cycle costing (LCC) as a contribution to sustainable construction: a common methodology literature review. London, 2007. Disponível em: http://ec.europa.eu/DocsRoom/documents/5059/attachments/1/translations/en/renditions/native. Acesso em: 15 out. 2019.

DEJACO, M. C.; CECCONI, F. R.; MALTESE, S. Key performance indicators for building condition assessment. Jounral of building engineering, v. 9, p. 17-28, 2017.

DEPARTMENT OF HOUSING AND PUBLIC WORKS. Maintenance management framework: building condition assessment. $2^{\text {nd }}$ ed. Brisbane, 2017. Disponível em: http://www.hpw.qld.gov.au/SiteCollectionDocuments/MMFBca.pdf. Acesso em: 15 out. 2019.

ELHAKEEM, A. A. M. An asset management framework for education buildings with life-cycle cost analysis. Waterloo, 2005. 152 f. Tese (Doutorado em Engenharia Civil) - University of Waterloo, Waterloo, 2005.

EWEDA, A.; ZAYED, T.; ALKASS, S. An integrated condition assessment model for buildings. In: PROCEEDINGS of the Construction Research Congress 2010. Aberta, 2010.

FONSECA, R.P. A estrutura do Instituto Central de Ciências: aspectos históricos, científicos e tecnológicos de projeto, execução, intervenções e proposta de manutenção. Brasília, 2007. 213 f. Dissertação (Mestrado em Engenharia Civil) - Faculdade de Tecnologia, Universidade de Brasília, Brasília, 2007.

HM TREASURY. The green book. Central government guidance on appraisal and evaluation. London, 2018. Disponível em:

https://assets.publishing.service.gov.uk/government/uploads/system/uploads/attachment_data/file/685903/T he_Green_Book.pdf. Acesso em: 15 out. 2019. 
INSTITUT DE TECNOLOGIA DE LA CONSTRUCCIÓ DE CATALUNYA. Manteniment de l'edifici: fitxes. Barcelona: ITEC, 1991a.

INSTITUT DE TECNOLOGIA DE LA CONSTRUCCIÓ DE CATALUNYA. Manteniment: installacions: fitxes. Barcelona: ITEC, 1991b.

INSTITUT DE TECNOLOGIA DE LA CONSTRUCCIÓ DE CATALUNYA. Manteniment: urbanització: fitxes. Barcelona: ITEC, 1991c.

INSTITUTO BRASILEIRO DE AVALIAÇÕES E PERÍCIAS DE ENGENHARIA. Norma de inspeção predial nacional. São Paulo: IBAPE-Nacional, 2012. Disponível em: http://www.ibape-nacional.com.br. Acesso em: 15 out. 2019.

INTERNATIONAL ORGANIZATION FOR STANDARDIZATION. ISO 15686-5: buildings and constructed assets: service life planning: part 5: life-cycle costing. London, 2017.

KLEIN, D. et al. Critérios adotados na vistoria e avaliação de obras de arte. In: JORNADAS SUL AMERICANAS DE ENGENHARIA ESTRUTURAL, 25., Porto Alegre, 1991. Anais [...] Porto Alegre, 1991.

LATTEF, O. A. A.; KHAMIDI, M. F.; IDRUS, A. Behavioural issues in maintenance of university buildings. Journal of Retail and Leisure Property, v. 9, n. 5, p. 415-428, 2011.

LAVY, S.; SHOHET, I. M. Integrated maintenance management of hospital buildings: a case study. Construction Management and Economics, v. 22, p. 25-34, 2004.

LOPES, B. A. R. Sistema de manutenção predial para grandes estoques de edifícios: estudo para inclusão do componente estruturas de concreto. Brasília, 1998. Dissertação (Mestrado em Engenharia Civil) - Faculdade de Tecnologia, Universidade de Brasília, Brasília, 1998.

LOPES, J. T. D.; ALONSO, N. R. P. Avaliação de benfeitorias urbanas. In: INSTITUTO Brasileiro de Avaliações e Perícias de Engenharia de São Paulo. Engenharia de avaliações. São Paulo: Pini, 2007.

MARENJAK, S.; EL-HARAM, M. A.; HORNER, M. R. W. A generic approach to minimize whole life costs in the building industry. In: Greenwood, D. J. (ed.) ANNUAL ARCOM CONFERENCE, 19., Brighton, 2003. Proceedings [...] Brighton: University of Brighton, 2003.

MAYO, G.; KARANJA, P. Current state of practice for condition assessment methods and the facility condition index as measure. CFaR034-16. APPA, 2017.

NATIONAL CENTER FOR EDUCATION STATISTICS. Facilities information management: a guide for state and local education agencies. NCES 2003-400. U.S. Department of Education, Washington, 2003.

RODRIGUES, R. M. G. C. Gestão de edifício. Modelo de simulação técnico-econômica. Porto, 2001. 202 f. Tese (Doutorado em Engenharia Civil) - Faculdade de Engenharia, Universidade do Porto, Porto, 2001.

ROYAL INSTITUTE OF CHARTERED SURVEYORS. Stock condition surveys. RICS guidance note, $2^{\text {nd }}$ Ed. London, 2005.

SHOHET, I. M. Building evaluation methodology for setting maintenance priorities in hospital buildings. Construction Management and Economics, v 21, p. 681-692, 2003.

SHOHET, I. M. Key performance indicators for strategic healthcare facilities maintenance. Journal of Construction Engineering and Management, v. 132, n. 4, p. 345-352, apr. 2006.

SHOHET, I. M.; LAVY, S. Development of an integrated healthcare facilities management model. Facilities. v. 22, n. 5/6, p. 129-140, 2004b.

SHOHET, I. M.; LAVY, S. Healthcare facilities management: state of the art review. Facilities. v. 22, n. 7/8, p. 210-220, 2004a.

SHOHET, I. M.; LAVY-LEIBOVICH, S.; BAR-ON, D. Integrated maintenance monitoring of hospital buildings. Construction Management and Economics, v. 21, p. 219-228, 2003.

STRAUB, A. Dutch standard for condition assessment of buildings. Structural Survey, v. 27, n. 1, p. 2335, 2009.

STRAUB, A. Using a condition-dependent approach to maintenance to control costs and performances. Journal of Facilities Management, v. 1, n. 4, p. 380-395, 2002. 


\section{TRIBUNAL DE JUSTIÇA DO DISTRITO FEDERAL E DOS TERRITÓRIOS. Plano de manutenção} predial preventiva das edificações do TJDFT. Brasília: SUMAN/TJDFT, 2013.

UZARSKI, D. R.; GRUSSING, M. N. Building condition assessment metrics: best practices. In: INFRASTRUCUTURE reporting and asset management: best practices and opportunities. 2008.

UZARSKI, D. R.; GRUSSING, M. N.; CLAYTON, J. B. Knowledge-based condition survey inspection concepts. Journal of Infrastructure Systems, v. 13, n. 1, p. 72-79, 2007.

\section{Francisco Morato Leite}

Programa de Pós-Graduação em Engenharia Civil | Universidade Estadual de Londrina | Rodovia Celso Garcia Cid, Km 380, Campus Universitário | Londrina - PR - Brasil | Caixa Postal 10.011| CEP 86057-970 | Tel.: (43) 3371-4727| E-mail: morato@uel.br

\section{Renan Alves Volse}

Rua Benjamin Constant, 1851/ 1305, Centro | Londrina - PR - Brasil | CEP 86020-320 | Tel.: (43) 99691-7149 | E-mail:

renan.avolse@gmail.com

\section{Humberto Ramos Roman}

Departamento de Engenharia Civil | Universidade Federal de Santa Catarina | Campus Universitário Trindade | Florianópolis - SC - Brasil | CEP 88049-900 | Tel.: (48) 3721-2394 | E-mail: humberto.roman@ufsc.br

\section{Fernanda Aranha Saffaro}

Programa de Pós-Graduação em Engenharia Civil | Universidade Estadual de Londrina | E-mail: saffaro@uel.br

\section{Ambiente Construído}

Revista da Associação Nacional de Tecnologia do Ambiente Construído

Av. Osvaldo Aranha, 99 - 3o andar, Centro

Porto Alegre - RS - Brasil

CEP 90035-190

Telefone: +55 (51) 3308-4084

Fax: +55 (51) 3308-4054

www. seer. ufrgs. br/ ambienteconstruido

E-mail: ambienteconstruido@ufrgs.br 